\title{
BIOACTIVE COMPOUNDS AND ANTIOXIDANT ACTIVITY OF MANGABA
}

\author{
COMPOSTOS BIOATIVOS E ATIVIDADE ANTIOXIDANTE DE MANGABA
}

\author{
Cristiane Maria Ascari Morgado; Ana Carolina da Silva Lima²; Ana Paula Silva Siqueira³; \\ Eli Regina Barboza de Souza ${ }^{4}$; Luis Carlos Cunha Junior ${ }^{5}$ \\ 1. Pós-doutoranda em Agronomia (Produção Vegetal), Programa de Pós-Graduação em Agronomia, Universidade Federal de Goiás - \\ UFG, Goiânia, GO, Brasil. cristianemorgado4@yahoo.com.br; 2. Doutoranda em Nutrição e Saúde, Faculdade de Nutrição, \\ Universidade Federal de Goiás - UFG, Goiânia, GO, Brasil; 3. Professora, Doutora, Instituto Federal Goiano - IF Goiano, Urutaí, GO, \\ Brasil; 4. Professora, Doutora, Universidade Federal de Goiás - UFG, Goiânia, GO, Brasil; 5. Professor, Doutor, Universidade Federal \\ de Goiás - UFG, Goiânia, GO, Brasil.
}

\begin{abstract}
The present study aimed to assess the behavior of bioactive compounds and total antioxidant activity of two mangaba varieties ( $H$. speciosa var. gardneri and $H$. speciosa var. cuyabensis) during storage, in two ripening stages. The fruit were harvested from the Germplasm bank of the School of Agronomy, at two ripening stages: "mature green" (mature fruit picked from the tree) and "fallen" (ripe fruit collected from the ground). After collection, they were transported to the laboratory, washed under running water, immersed in chlorine solution at $100 \mathrm{mg} \mathrm{L}^{-1}$ for 10 minutes, left to dry and stored under ambient conditions $\left(22 \pm 1^{\circ} \mathrm{C}\right.$ and $\left.90 \pm 5 \% \mathrm{RH}\right)$. The fruit were analyzed to determine ascorbic acid content, total extractable polyphenols, yellow flavonoids and antioxidant activity using ferric reducing antioxidant power (FRAP) and ABTS (2,2'-azino-bis-(3-ethylbenzthiazoline-6-sulfonic acid). Analyses were performed daily until the mangaba were unfit for sale, using 3 repetitions with 3 fruit each. The maximum conservation time was eight days for "mature green" and two days for "fallen" fruit. The cuyabensis variety exhibited greatest ascorbic acid content at both ripening stages, in addition to higher antioxidant activity, and was therefore found to have the best potential to be marketed as a "superfruit".
\end{abstract}

KEYWORDS: Antioxidant capacity. Cerrado. H. speciosa var. cuyabensis. H. speciosa var. gardneri.

\section{INTRODUCTION}

Certain areas of Brazil enable the cultivation of different types of fruit and are home to native and understudied species with the potential to become "superfruits". The most prominent of these regions is the Cerrado biome, the country's second largest area of vegetation with a wide variety of fruits known for their unique flavor and high nutritional value (LIMA, 2011).

These include the mangabeira tree (Hancornia speciosa Gomes), which produces an aromatic, nutritious and pleasant-tasting fruit (CALDAS et al., 2009), known as the mangaba. The industrial potential of this fruit lies in the fact that it contains around $77 \%$ flesh, on average, and only $23 \%$ skin and seeds. The mangaba is valued by the local community, but commercially underexplored; it is generally consumed fresh or processed for juice only by the population closest to where it is harvested. Its high nutritional value is due to the mangaba's high levels of vitamins A, B1, B2, and C, iron, phosphorus, calcium and bioactive compounds (SOARES et al., 2004).

Moreover, the consumption of fruit with functional properties has increased, due to the presence of bioactive compounds that exhibit additional physiological effects, even in small amounts (LIMA et al., 2004; MELO et al., 2008). As such, mangaba has the potential to be classified as a "superfruit" and its consumption could provide a variety of health benefits, including a lower incidence of degenerative and cardiovascular diseases (CARDOSO, 2011; PRIOR et al., 2005; XIAO, 2016), thus demonstrating its potential for the consumer market.

However, it is still essentially an undomesticated species and there are almost no organized fruit orchards aimed at its rational exploitation for production (GANGA et al., 2009). In order to reach new markets, it is essential to implement commercial orchards since current production is unable to meet the demands of even local consumers (LEDERMAN et al., 2000).

In this respect, in 2005 the School of Agronomy of the Federal University of Goiás implemented the mangaba germplasm, with seeds from more than 100 mother plants located in the states of Goiás, Tocantins, Bahia, Mato Grosso and Mato Grosso do Sul. Ninety progenies of halfbrothers of these mother plants were planted in the field (GANGA, 2008). In 2010, another collection was compiled, consisting of the progenies of 116 mother plants from different regions in Goiás state 
Bioactive compounds...

(VIEIRA, 2011), enabling studies to be conducted on the domestication of these species (GANGA et al., 2009; COLLEVATTI et al., 2016).

The short shelf life of mangaba may be exacerbated by the fact that the fruit is manually harvested once it has fallen to the ground. This results in mechanical damage to the fragile skin, accelerating metabolism and reducing storage time (MOKADY et al., 1984), in addition to degrading bioactive compounds, which limits the commercial exploitation of the crop for specific markets (VIEIRA et al., 2010).

The first step is to harvest the fruit directly from the plant at a suitable ripening stage for the species (MATTOS; ALMEIDA, 2006), in order to ensure longer storage times and enable distribution. In this regard, Vieira Neto et al. (2002) reported that mangaba fruit harvested directly from the mother tree ("mature green") can be stored until fully ripe, extending the commercialization period to 12 days in relation to those collected from the ground (6 days). This is attributed to the reduction in mechanical injury caused by natural falling (CARNELOSSI et al., 2004; SANTOS et al., 2009; SILVA et al., 2013).

During ripening, fruit undergoes physical, chemical, biochemical and physiological changes that lead to visible modifications in color, flavor, aroma and texture (PRASANNA et al., 2007). Several authors have identified notable differences in the bioactive compound content and antioxidant activity of other types of fruit at different ripening stages (SANTOS, 2011; MORGADO et al., 2010; PARK et al., 2006; ZHANG et al., 2006). However, there are no published studies investigating the metabolism of bioactive compounds during storage of mangaba fruit harvested at different times, and this information is vital to ensuring it can be marketed as a "superfruit" and reach a wider market.

The literature on mangaba does not identify the variety used, and the genetic factor of each variety can influence storage time as well as the behavior of bioactives, since ripening characteristics are affected not only by climate conditions and crop management systems, but genetic characteristics (SOUZA, 2012; LEE; KADER, 2000). Thus, the present study aimed to assess the behavior of bioactive compounds and total antioxidant activity of two mangaba varieties (H. speciosa var. gardneri and $H$. speciosa var. cuyabensis) during storage, in two ripening stages.
MORGADO, C. M. A. et al.

\section{MATERIAL AND METHODS}

\section{Fruit material}

Fruit of both varieties (Hancornia speciosa var. gardneri and $H$. speciosa var. cuyabensis) were harvested in the early morning at the germplasm belonging to the School of Agronomy of the Federal University of Goiás, EA-UFG $\left(16^{\circ} 35^{\text {"c } 39^{\prime \prime}} \mathrm{S}\right.$ latitude, $49^{\circ} 17^{\text {ee }} 07^{\prime \prime} \mathrm{W}$ longitude and altitude of 733 $\mathrm{m})$. They were collected at two ripening stages: stage 1 - "mature green" (mature fruit picked from the tree) and stage 2 - "fallen" (ripe fruit collected from the ground, after shaking the trees), with 90 mangaba fruit of each variety collected for each stage.

After harvesting, the fruit were stored in plastic crates covered with bubble wrap and transported to the laboratory of the EA-UFG Horticulture Department, where they were selected and standardized, using only intact fruit (no insect damage, visible lesions or symptoms of disease) with uniform coloring for each ripening stage. The mangaba were washed under running water, immersed in a sodium hypochlorite solution at 100 $\mathrm{mg} \mathrm{L}^{-1}$ for 10 minutes, then dried and stored at $22 \pm 1^{\circ} \mathrm{C}$ and $90 \pm 5 \%$ relative humidity (RH).

The fruit were chemically and physically characterized at the start of the experiment (Table $1)$.

\section{Experimental design}

A completely randomized design was used, with a double factorial scheme as follows: I - days of storage; II - variety, for each ripening stage ("mature green" and "fallen"). The fruit were assessed daily until they became unfit for consumption, using three repetitions with three mangaba each. The fruit were analyzed to determine ascorbic acid content, total extractable polyphenols, yellow flavonoids and antioxidant activity using ferric reducing antioxidant power (FRAP) and ABTS.

\section{Assessments \\ Initial mangaba characterization}

Soluble solid (SS) content was quantified in drops extracted from the ground pulp through direct reading on a handheld refractometer (Instrutemp ITREF 82), with results expressed in percent (AOAC, 2012 - method 932.12). 
Table 1. Mean values for soluble solids (SS), titratable acidity (TA), maturity index (SS/TA), and firmness (FIR) of two Hancornia speciosa varieties, harvested at two ripening stages from the germplasm belonging to the School of Agronomy of the Federal University of Goiás.

\begin{tabular}{|c|c|c|c|c|}
\hline \multirow[t]{2}{*}{ Variety } & $\mathbf{S S}^{*}$ & TA & SS/TA & FIR \\
\hline & \multicolumn{4}{|c|}{ Ripening stage - "mature green" } \\
\hline Gardneri & $15.83 \pm 0.76^{*}$ & $0.64 \pm 0.05$ & $25.05 \pm 3.01$ & $2.11 \pm 0.39$ \\
\hline Cuyabensis & $16.67 \pm 0.76$ & $0.74 \pm 0.08$ & $22.60 \pm 3.05$ & $2.46 \pm 0.64$ \\
\hline \multicolumn{5}{|c|}{ Ripening stage - "fallen" } \\
\hline Gardneri & $19.00 \pm 0.00$ & $0.93 \pm 0.06$ & $20.40 \pm 1.20$ & $0.10 \pm 0.01$ \\
\hline Cuyabensis & $21.83 \pm 1.04$ & $1.05 \pm 0.10$ & $20.84 \pm 1.86$ & $0.17 \pm 0.03$ \\
\hline
\end{tabular}

${ }^{*}$ Means followed by standard deviation. Nine fruit were sampled.

Titratable acidity (TA) was quantified in 5 grams of ground pulp diluted in $45 \mathrm{~mL}$ of distilled water, by titration with $0.1 \mathrm{~mol} \mathrm{~L}^{-1} \mathrm{NaOH}$ using phenolphthalein as indicator. The results were expressed in percent citric acid (AOAC, 2012method 942.15).

The maturity index (SS/TA) was calculated by dividing $\mathrm{SS}$ values by TA.

Firmness was determined using applanation tonometry in accordance with Calbo; Nery (1995), whereby the force needed to flatten a circular area $(\mathrm{A}=0.784 \mathrm{x}$ greatest length $\mathrm{x}$ smallest length $)$ of the fruit was calculated by F/A, where $F$ is the force exerted by the glass plate (based on its weight); the result was expressed in Newton $(\mathrm{N})$.

\section{Bioactive compound analyses}

Ascorbic acid content was determined by titration, in line with Strohecker; Henning (1967). A 0.5 -gram sample of ground pulp was weighed and added with $10 \mathrm{ml}$ of cold $0.5 \%$ oxalic acid, followed by titration with a 2.6 dichlorophenolindophenol solution (DFNa) until pink coloring was visible. The results were expressed in $\mathrm{mg}$ of ascorbic acid $100 \mathrm{~g}^{-}$ ${ }^{1}$ of pulp.

Total extractable polyphenol (TEP) levels were measured using the method proposed by Obanda; Owuor (1997). A 4.0-gram sample of ground pulp was weighed, added with $20 \mathrm{ml}$ of $50 \%$ methanol and left to stand for an hour. Next, it was centrifuged and $20 \mathrm{ml}$ of $70 \%$ acetone was added to the residue and left for one hour. The sample was then centrifuged again and the extract obtained. TEP was quantified using the Folin-Ciocalteu method and the results were expressed in milligrams of gallic acid $100 \mathrm{~g}^{-1}$ of pulp.

Yellow flavonoids were determined according Francis (1982). A 4.0-gram sample of ground pulp was weighed, added with $30 \mathrm{ml}$ of ethanol $(95 \%)-\mathrm{HCl}(1.5 \mathrm{M})$ at a proportion of $85: 15$, and mixed for 2 minutes. Next, the volume was completed to $50 \mathrm{ml}$ with ethanol-HCL $(1.5 \mathrm{M})$ and left overnight in a refrigerator. The extract was filtered and absorbance read at $374 \mathrm{~nm}$. The results were expressed in milligrams $100 \mathrm{~g}^{-1}$ of pulp.

Total antioxidant activity was determined in the same extract used for TEP, by $\mathrm{Fe}^{3}+$ reduction (FRAP - ferric-reducing antioxidant power). This method is based on a reduction reaction (in acid) of the ferric tripyridyltriazine complex to the ferrous complex, whose color changes to blue in the presence of an antioxidant (Benzie and Strain, 1996; Pulido et al., 2000). The results were expressed in $\mu \mathrm{M}$ of ferrous sulfate $\mathrm{g}^{-1}$ of pulp for the FRAP assay and $\mu \mathrm{M}$ of trolox $\mathrm{g}^{-1}$ of pulp for ABTS free radical scavenging (2,2'-azino-bis-(3-ethylbenzthiazoline6 -sulfonic acid), as described by Rufino (2008).

\section{Statistical analysis}

\section{Univariate analysis}

The results were statistically analyzed using SISVAR software (FERREIRA, 2014). The data were submitted to analysis of variance by the F-test and the means were assessed throughout storage using Tukey's test at 5\% significance.

\section{Multivariate analysis}

Hierarchical clustering. Hierarchical clustering analysis was performed for both the varieties studied, using the Euclidean distance as similarity coefficient and Ward's algorithm as clustering strategy (HAIR et al., 2009) to identify the differences between varieties at each ripening stage.

Principal components analysis (PCA). The PCA technique generates orthogonal latent variables, centered in the region with the highest variability. To that end, a covariance matrix was calculated and eigenvalues extracted. These generate eigenvectors (principal components or PCs), which are linear combinations of the original variables. The Kaiser criterion was applied considering eigenvalues $>1$, which produce components containing at least as much information as the original data (KAISER, 1958). 
Hierarchical clustering and principal component analysis were performed using Statistica software (STATSOFT INC., 2004).

\section{RESULTS}

\section{Univariate analysis}

\section{"Mature green" fruit}

The cuyabensis variety obtained the highest ascorbic acid concentrations, total extractable polyphenols and total antioxidant activity, measured by FRAP and ABTS. Yellow flavonoid content did not differ significantly between the two varieties studied (Table 2).

Table 2. Ascorbic acid content (AA), yellow flavonoids (FLAV), total extractable polyphenols (TEP) and antioxidant activity determined by FRAP and ABTS, for two Hancornia speciosa varieties harvested at the "mature green" ripening stage from the germplasm bank of the School of Agronomy of the Federal University of Goiás, and stored at $22 \pm 1^{\circ} \mathrm{C}$ and $90 \pm 5 \% \mathrm{RH}$.

\begin{tabular}{lccccc}
\hline \multicolumn{1}{c}{ Varieties } & AA & FLAV & TEP & FRAP & ABTS \\
\hline Gardneri & $140.45 \mathrm{~b}$ & $3.65 \mathrm{a}$ & $32.22 \mathrm{~b}$ & $12.38 \mathrm{~b}$ & $5.74 \mathrm{~b}$ \\
Cuyabensis & $168.03 \mathrm{a}$ & $3.86 \mathrm{a}$ & $41.79 \mathrm{a}$ & $16.53 \mathrm{a}$ & $9.41 \mathrm{a}$ \\
\hline F-Test & $25.60^{* *}$ & $1.50^{\mathrm{NS}}$ & $37.88^{* *}$ & $267.34^{* *}$ & $911.29^{* *}$ \\
LSD & 11.06 & 0.36 & 3.15 & 0.52 & 0.25 \\
\hline Days & & & & & \\
0 & $136.03 \mathrm{c}$ & $3.40 \mathrm{bc}$ & $48.91 \mathrm{a}$ & $15.88 \mathrm{a}$ & $11.05 \mathrm{a}$ \\
1 & $151.43 \mathrm{abc}$ & $2.79 \mathrm{bc}$ & $29.28 \mathrm{~d}$ & $15.89 \mathrm{a}$ & $4.85 \mathrm{e}$ \\
2 & $141.34 \mathrm{bc}$ & $2.62 \mathrm{c}$ & $29.20 \mathrm{~d}$ & $11.38 \mathrm{c}$ & $5.28 \mathrm{e}$ \\
3 & $186.72 \mathrm{a}$ & $3.26 \mathrm{bc}$ & $37.40 \mathrm{bcd}$ & $14.09 \mathrm{~b}$ & $7.20 \mathrm{~d}$ \\
4 & $153.31 \mathrm{abc}$ & $3.79 \mathrm{bc}$ & $39.07 \mathrm{abcd}$ & $14.96 \mathrm{ab}$ & $9.07 \mathrm{~b}$ \\
5 & $133.66 \mathrm{c}$ & $3.86 \mathrm{~b}$ & $30.66 \mathrm{~cd}$ & $11.38 \mathrm{c}$ & $7.77 \mathrm{~cd}$ \\
6 & $178.56 \mathrm{ab}$ & $3.62 \mathrm{bc}$ & $33.50 \mathrm{bcd}$ & $15.56 \mathrm{ab}$ & $7.22 \mathrm{~d}$ \\
7 & $187.77 \mathrm{a}$ & $3.83 \mathrm{bc}$ & $41.11 \mathrm{abc}$ & $14.97 \mathrm{ab}$ & $8.24 \mathrm{bc}$ \\
8 & $119.59 \mathrm{c}$ & $6.65 \mathrm{a}$ & $43.93 \mathrm{ab}$ & $15.99 \mathrm{a}$ & $7.52 \mathrm{~cd}$ \\
\hline F-Test & $9.14^{* *}$ & $19.72^{* *}$ & $8.83^{* *}$ & $23.40^{* *}$ & $104.62^{* *}$ \\
LSD & 38.14 & 1.23 & 10.88 & 1.78 & 0.85 \\
\hline Interaction (5\%) & $2.60^{*}$ & $1.96^{\mathrm{NS}}$ & $5.08^{* *}$ & $14.47^{* *}$ & $92.35^{* *}$ \\
CV $(\%)$ & 12.99 & 17.21 & 15.44 & 6.45 & 5.89 \\
\hline
\end{tabular}

Interaction (5\%) is the result of species-day interaction. Means followed by at least one same letter in a column do not differ according to Tukey's test $(\mathrm{p}>0.05) .{ }^{* *}=$ significant at $1 \%$ probability; ${ }^{*}=$ significant at $5 \%$ probability according to the F-test. NS $=$ not significant. AA Ascorbic acid (mg ascorbic acid $100 \mathrm{~g}^{-1}$ of pulp), FLAV yellow flavonoids ( $\mathrm{mg} 100 \mathrm{~g}^{-1} \mathrm{of} \mathrm{pulp}$ ), TEP total extractable polyphenols (mg gallic acid $100 \mathrm{~g}^{-1}$ of pulp) and FRAP and ABTS are antioxidant activity by ferric reducing antioxidant power FRAP ( $\mu \mathrm{M}$ of ferrous sulfate $\mathrm{g}^{-1}$ of pulp) and ABTS free radical scavenging ( $\mu \mathrm{M}$ of trolox $\mathrm{g}^{-1}$ of pulp), respectively.

Ascorbic acid content in the gardneri variety fluctuated during storage, with a significant increase on day 7 (54\% higher in relation to day zero) and a decline the following day. The highest level for the cuyabensis variety was recorded on the third day (39\% greater than day zero), followed by a decrease from day 6 until the end of storage (Table $3)$.

Yellow flavonoid content remained stable for both varieties until day 7; however, there was a significant increase from 3.03 to $7.45 \mathrm{mg} 100 \mathrm{~g} \mathrm{~g}^{-1}$ of pulp for gardneri and 3.77 to $5.85 \mathrm{mg} 100 \mathrm{~g}^{-1}$ of pulp for cuyabensis on the last day (Table 3).

Total extractable polyphenol content varied significantly during storage of the gardneri variety, whereas no significant differences were observed between storage days for cuyabensis (Table 3).
Total antioxidant activity was determined by FRAP for both varieties (gardneri and cuyabensis) and fluctuated during storage; however, at the end of the storage period, differences were not significant when compared to activity on harvesting day. With respect to AA assessed using the ABTS method, both varieties showed a trend toward decreasing antioxidant activity during storage (Table 3 ). 
Table 3. Behavior of ascorbic acid content (AA), yellow flavonoids (FLAV), total extractable polyphenols (TEP) and antioxidant activity determined by FRAP and ABTS, for two Hancornia speciosa varieties harvested at the "mature green" ripening stage from the germplasm bank of the School of Agronomy of the Federal University of Goiás, and stored at $22 \pm 1{ }^{\circ} \mathrm{C}$ and $90 \pm 5 \% \mathrm{RH}$.

\begin{tabular}{|c|c|c|c|c|c|c|c|c|c|}
\hline \multirow[t]{3}{*}{ Variety } & \multicolumn{9}{|c|}{ Days } \\
\hline & $\mathbf{0}$ & 1 & 2 & 3 & 4 & 5 & 6 & 7 & 8 \\
\hline & \multicolumn{9}{|c|}{ Ascorbic acid } \\
\hline Gardneri & $118.9 \mathrm{bBC}$ & $149.7 \mathrm{aABC}$ & $121.4 \mathrm{bBC}$ & $160.6 \mathrm{bAB}$ & $149.6 \mathrm{aABC}$ & $100.9 \mathrm{bC}$ & $154.2 \mathrm{bABC}$ & $182.7 \mathrm{aA}$ & $125.5 \mathrm{aBC}$ \\
\hline Cuyabensis & $153.1 \mathrm{aBC}$ & $153.1 \mathrm{aBC}$ & 161.2aABC & $212.7 \mathrm{aA}$ & $156.9 \mathrm{aBC}$ & 166.3aABC & $202.8 \mathrm{aAB}$ & $192.3 \mathrm{aAB}$ & $113.6 \mathrm{aC}$ \\
\hline \multicolumn{10}{|c|}{ Yellow flavonoids } \\
\hline Gardneri & $3.03 \mathrm{aB}$ & $2.27 \mathrm{aB}$ & $2.42 \mathrm{aB}$ & $3.18 \mathrm{aB}$ & $3.58 \mathrm{aB}$ & $3.77 \mathrm{aB}$ & $3.54 \mathrm{aB}$ & $3.62 \mathrm{aB}$ & $7.45 \mathrm{aA}$ \\
\hline Cuyabensis & $3.77 \mathrm{aB}$ & $3.31 \mathrm{aB}$ & $2.81 \mathrm{aB}$ & $3.35 \mathrm{aB}$ & $3.99 \mathrm{aB}$ & $3.96 \mathrm{aB}$ & $3.71 \mathrm{aB}$ & $4.04 \mathrm{aB}$ & $5.85 \mathrm{bA}$ \\
\hline \multicolumn{10}{|c|}{ Total extractable polyphenols } \\
\hline Gardneri & $55.97 \mathrm{aA}$ & $20.49 \mathrm{bC}$ & $20.80 \mathrm{bC}$ & $27.69 \mathrm{bBC}$ & $32.66 \mathrm{bBC}$ & $22.46 \mathrm{bC}$ & $29.46 \mathrm{aBC}$ & $38.34 \mathrm{aB}$ & $42.10 \mathrm{aAB}$ \\
\hline Cuyabensis & $41.86 \mathrm{bA}$ & $38.06 \mathrm{aA}$ & $37.59 \mathrm{aA}$ & $47.11 \mathrm{aA}$ & $45.48 \mathrm{aA}$ & $38.85 \mathrm{aA}$ & $37.54 \mathrm{aA}$ & $43.88 \mathrm{aA}$ & $45.76 \mathrm{aA}$ \\
\hline \multicolumn{10}{|c|}{ FRAP } \\
\hline Gardneri & $14.07 \mathrm{bABC}$ & $15.89 \mathrm{aA}$ & $7.62 \mathrm{bD}$ & $12.06 \mathrm{bC}$ & $13.20 \mathrm{bBC}$ & $6.52 \mathrm{bD}$ & $13.72 \mathrm{bABC}$ & $13.19 \mathrm{bBC}$ & $15.15 \mathrm{bAB}$ \\
\hline Cuyabensis & $17.69 \mathrm{aA}$ & $15.89 \mathrm{aAB}$ & $15.14 \mathrm{aB}$ & $16.12 \mathrm{aAB}$ & $16.71 \mathrm{aAB}$ & $16.26 \mathrm{aAB}$ & $17.40 \mathrm{aAB}$ & $16.76 \mathrm{aAB}$ & $16.83 \mathrm{aAB}$ \\
\hline \multicolumn{10}{|c|}{ ABTS } \\
\hline Gardneri & $11.48 \mathrm{aA}$ & $3.19 \mathrm{bD}$ & $3.13 \mathrm{bD}$ & $3.45 \mathrm{bD}$ & $7.48 \mathrm{bB}$ & $2.87 \mathrm{bD}$ & $4.66 \mathrm{bC}$ & $8.19 \mathrm{aB}$ & $7.26 \mathrm{aB}$ \\
\hline Cuyabensis & $10.62 \mathrm{bB}$ & $7.37 \mathrm{aCD}$ & $6.57 \mathrm{aD}$ & $10.95 \mathrm{aB}$ & $10.66 \mathrm{aB}$ & $12.67 \mathrm{aA}$ & $9.79 \mathrm{aB}$ & $8.29 \mathrm{aC}$ & $7.78 \mathrm{aC}$ \\
\hline
\end{tabular}




\section{"Fallen" fruit}

The highest ascorbic acid concentrations were recorded in the cuyabensis variety, while gardneri obtained the highest total extractable polyphenol levels. With respect to yellow flavonoids and total antioxidant activity (FRAP and ABTS), there were no significant differences between the two varieties (Table 4).

Table 4. Ascorbic acid content (AA), yellow flavonoids (FLAV), total extractable polyphenols (TEP) and antioxidant activity determined by FRAP and ABTS, for two Hancornia speciosa varieties harvested at the "fallen" ripening stage from the germplasm bank of the School of Agronomy of the Federal University of Goiás, and stored at $22 \pm 1^{\circ} \mathrm{C}$ and $90 \pm 5 \%$ RH.

\begin{tabular}{lccccc}
\hline \multicolumn{1}{c}{ Varieties } & AA & FLAV & TEP & FRAP & ABTS \\
\hline Gardneri & $171.95 \mathrm{~b}$ & $7.61 \mathrm{a}$ & $49.35 \mathrm{a}$ & $18.11 \mathrm{a}$ & $12.10 \mathrm{a}$ \\
Cuyabensis & $198.98 \mathrm{a}$ & $8.12 \mathrm{a}$ & $44.51 \mathrm{~b}$ & $18.02 \mathrm{a}$ & $11.41 \mathrm{a}$ \\
\hline F-Test & $23.09^{* * *}$ & $0.84^{\mathrm{NS}}$ & $18.76^{* *}$ & $0.40^{\mathrm{NS}}$ & $1.91^{\mathrm{NS}}$ \\
LSD & 12.26 & 1.25 & 2.43 & 0.31 & 1.09 \\
\hline Days & & & & & \\
0 & $161.51 \mathrm{~b}$ & $8.82 \mathrm{a}$ & $41.62 \mathrm{c}$ & $18.66 \mathrm{a}$ & $13.98 \mathrm{a}$ \\
1 & $194.15 \mathrm{a}$ & $7.40 \mathrm{a}$ & $45.74 \mathrm{~b}$ & $17.42 \mathrm{c}$ & $10.71 \mathrm{~b}$ \\
2 & $200.74 \mathrm{a}$ & $7.38 \mathrm{a}$ & $53.44 \mathrm{a}$ & $18.12 \mathrm{~b}$ & $10.58 \mathrm{~b}$ \\
\hline F-Test & $18.59^{* *}$ & $2.79^{\mathrm{NS}}$ & $38.39^{* *}$ & $25.67^{* *}$ & $19.68^{* *}$ \\
LSD & 18.39 & 1.88 & 3.65 & 0.46 & 1.64 \\
\hline Interaction $(5 \%)$ & $0.98^{\mathrm{NS}}$ & $5.18^{*}$ & $71.56^{* *}$ & $7.17^{* *}$ & $3.38^{\mathrm{NS}}$ \\
CV $(\%)$ & 6.43 & 15.43 & 5.05 & 1.65 & 9.06 \\
\hline
\end{tabular}

Interaction (5\%) is the result of species-day interaction. Means followed by at least one same letter in a column do not differ according to Tukey's test $(\mathrm{p}>0.05) . * *=$ significant at $1 \%$ probability; $*=$ significant at $5 \%$ probability according to the $\mathrm{F}$ test. NS $=$ not significant. AA Ascorbic acid (mg ascorbic acid $100 \mathrm{~g}^{-1}$ of pulp), FLAV yellow flavonoids (mg $100 \mathrm{~g}^{-1}$ of pulp), TEP total extractable polyphenols (mg gallic acid $100 \mathrm{~g}^{-1}$ of pulp) and FRAP and ABTS are antioxidant activity by ferric reducing antioxidant power - FRAP ( $\mu$ M of ferrous sulfate $\mathrm{g}^{-1}$ of pulp) and ABTS free radical scavenging ( $\mu \mathrm{M}$ of trolox $\mathrm{g}^{-1}$ of pulp), respectively.

Ascorbic acid content increased significantly during storage, with a $23 \%$ and $26 \%$ rise in relation to day zero for the gardneri and cuyabensis varieties, respectively. Yellow flavonoid content showed no significant changes during storage, whereas a significant decline was observed for cuyabensis (Table 5).

Total extractable polyphenol levels fluctuated over the storage period; however, there was no difference between them on the last day of storage and harvesting day, with TEP content increasing during storage for the cuyabensis variety (Table 5).

Total antioxidant activity for gardneri, determined by FRAP, declined by $7 \%$ during storage, while cuyabensis mangaba exhibited reduced $\mathrm{AA}$ on the first day followed by an increase after 2 days (Table 5). When AA was measured by ABTS, both varieties exhibited declining levels during storage, with a $45 \%$ and $21 \%$ decrease for gardneri and cuyabensis, respectively.

\section{Multivariate analysis}

Hierarchical clustering was used to assess the behavior of the gardneri and cuyabensis varieties for the different ripening stages. The dendrogram generated clearly shows the formation of 4 distinct clusters when a Euclidean distance of 5 is used as the cutoff point. The groups formed in accordance with the variety and ripening stage. Thus, three groups of interest were identified among the 4 clusters, with group 1 consisting of gardneri mangaba picked in the "mature green" stage, group 2 of ripe fruit from both varieties, and group 3 of "fallen" cuyabensis mangaba (Figure 1).

The first two principal components (PC1 and PC2) explained $79.86 \%$ of the total variability of the original bioactive compound and total antioxidant activity data (Figure 2). PC1 revealed that all the bioactive compounds (ascorbic acid content, yellow flavonoids and total extractable polyphenols) and total antioxidant activity determined by FRAP and ABTS were positively correlated. The formation of three groups was observed (Figure 2), namely: Group 1: "Fallen", independent of the variety studied (positioned to the left of PC1 - negative side), Group 2: "Mature green", cuyabensis variety (in the center of the biplot) and Group 3: "Mature green", gardneri variety (to the right of PC1 -positive side). 
Table 5. Behavior of ascorbic acid content (AA), yellow flavonoids (FLAV), total extractable polyphenols (TEP) and antioxidant activity determined by FRAP and ABTS, for two Hancornia speciosa varieties harvested at the "fallen" ripening stage from the germplasm bank of the School of Agronomy of the Federal University of Goiás, and stored at $22 \pm 1{ }^{\circ} \mathrm{C}$ and $90 \pm 5 \% \mathrm{RH}$.

\begin{tabular}{|c|c|c|c|}
\hline \multirow[t]{2}{*}{ Variety } & \multicolumn{3}{|c|}{ Days } \\
\hline & $\mathbf{0}$ & 1 & 2 \\
\hline \multicolumn{4}{|c|}{ Ascorbic acid } \\
\hline gardneri & $152.69 \mathrm{aB}$ & $175.67 \mathrm{bAB}$ & $187.49 \mathrm{bA}$ \\
\hline cuyabensis & $170.33 \mathrm{aB}$ & $212.63 \mathrm{aA}$ & $213.98 \mathrm{aA}$ \\
\hline \multicolumn{4}{|c|}{\begin{tabular}{|l} 
Yellow flavonoids \\
\end{tabular}} \\
\hline gardneri & $8.41 \mathrm{aA}$ & $6.10 \mathrm{bA}$ & $8.31 \mathrm{aA}$ \\
\hline cuyabensis & $9.24 \mathrm{aA}$ & $8.71 \mathrm{aAB}$ & $6.44 \mathrm{aB}$ \\
\hline \multicolumn{4}{|c|}{ Total extractable polyphenols } \\
\hline gardneri & $53.49 \mathrm{aA}$ & $43.67 \mathrm{aB}$ & $50.90 \mathrm{bA}$ \\
\hline cuyabensis & $29.76 \mathrm{bC}$ & $47.81 \mathrm{aB}$ & $55.98 \mathrm{aA}$ \\
\hline \multicolumn{4}{|c|}{ FRAP } \\
\hline gardneri & $18.99 \mathrm{aA}$ & $17.54 \mathrm{aB}$ & $17.80 \mathrm{bB}$ \\
\hline cuyabensis & $18.34 \mathrm{bA}$ & $17.30 \mathrm{aB}$ & $18.43 \mathrm{aA}$ \\
\hline \multicolumn{4}{|c|}{ ABTS } \\
\hline gardneri & $14.53 \mathrm{aA}$ & $11.74 \mathrm{aB}$ & $10.04 \mathrm{aB}$ \\
\hline cuyabensis & $13.44 \mathrm{aA}$ & $9.68 \mathrm{bB}$ & $11.11 \mathrm{aB}$ \\
\hline
\end{tabular}

Means followed by the same letter, upper case in lines and lower case in columns, do not differ according to Tukey's test (p>0.05). Ascorbic acid (mg ascorbic acid $100 \mathrm{~g} \mathrm{~g}^{-1}$ of pulp), yellow flavonoids ( $\mathrm{mg} 100 \mathrm{~g} \mathrm{~g}^{-1}$ of pulp), total extractable polyphenols (mg gallic acid $100 \mathrm{~g}^{-1}$ of pulp) and antioxidant activity by ferric reducing antioxidant power - FRAP ( $\mu \mathrm{M}$ of ferrous sulfate $\mathrm{g}^{-1}$ of pulp) and ABTS free radical scavenging ( $\mu \mathrm{M}$ of trolox $\mathrm{g}^{-1}$ of pulp).

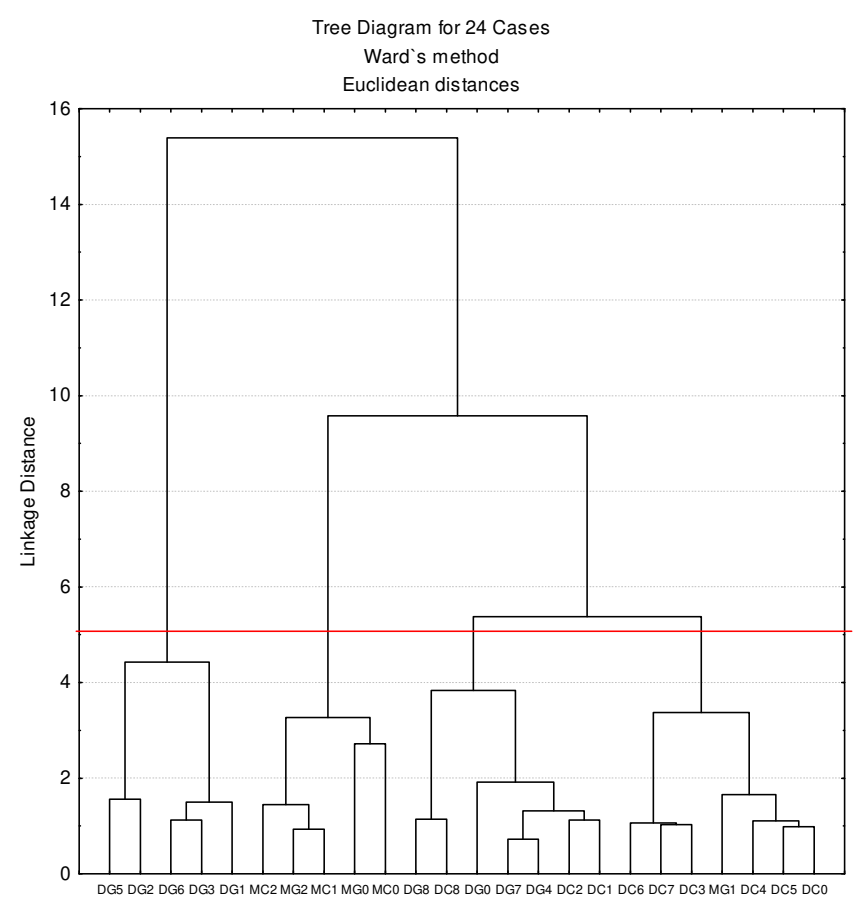

Figure 1. Hierarchical clustering analysis of two "mature green" and "fallen" Hancornia speciosa varieties harvested from the germplasm bank of the School of Agronomy of the Federal University of Goiás, and stored at $22^{\circ} \mathrm{C}$ and $90 \% \mathrm{RH}$. The letter D corresponds to the "mature green" stage; $\mathbf{M}$ to "fallen" fruit; $\mathbf{C}$ to the cuyabensis variety and $\mathbf{G}$ to gardneri. 


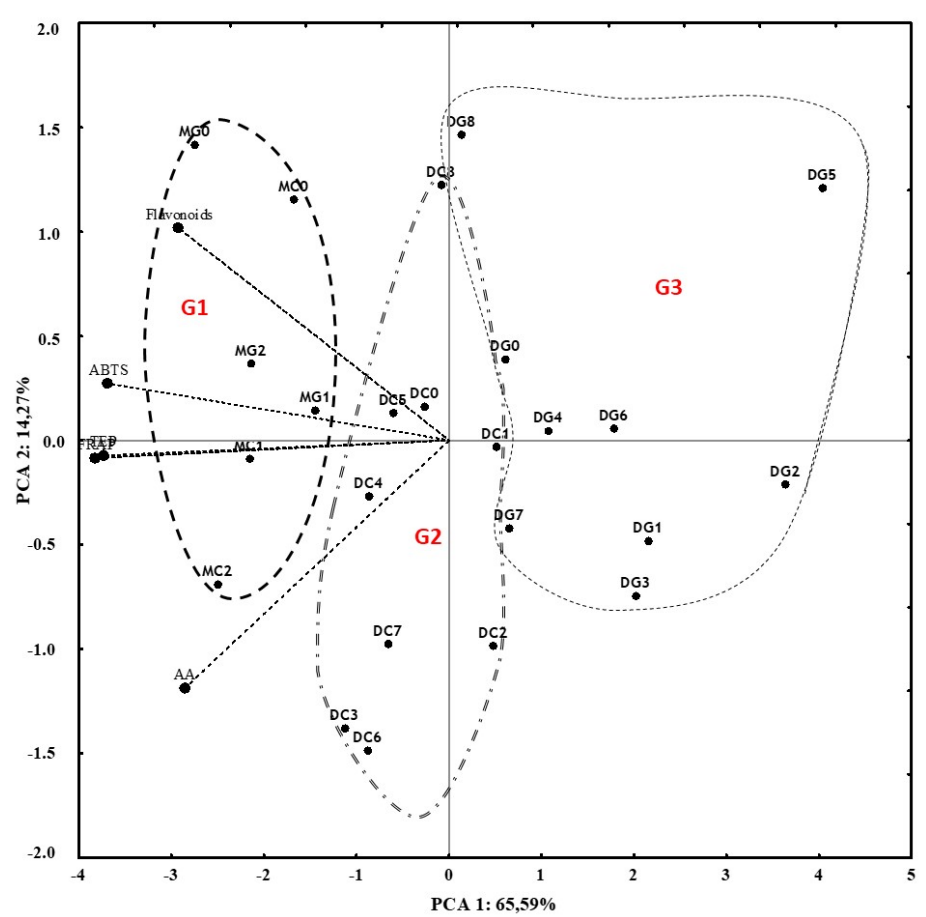

Figure 2. Principal Component Analysis of two "mature green" and "fallen" Hancornia speciosa varieties harvested from the germplasm bank of the School of Agronomy of the Federal University of Goiás, and stored at $22^{\circ} \mathrm{C}$ and $90 \% \mathrm{RH}$. The letter D corresponds to the "mature green" stage; $\mathrm{M}$ to "fallen" fruit; C to the cuyabensis variety and G to gardneri. G1, G2 and G3 correspond to groups 1,2 and 3 , respectively.

Thus, principal component analysis (PCA) was performed to visualize the distribution of samples within a two dimensional plane and analyze the power of each parameter based on the vectors formed (Figure 2), in order to better explain the division between the varieties and ripening stages in the dendrogram and indicate which variables interfered in cluster formation (Figure 1).

\section{DISCUSSION}

The shelf life of "fallen" mangaba stored at $22^{\circ} \mathrm{C}$ was only two days, regardless of variety. When the two varieties were harvested at the "mature green" stage and stored at the same temperature their shelf life increased to eight days. The maximum conservation period for "mature green" fruit was eight days, similar to the 9-day shelf life reported by Campos et al. (2011) for "mature green" mangaba stored under ambient conditions. By contrast, the shelf life of ripe mangaba in this study was only two days, similar to the result obtained by Carnelossi et al. (2004) for ripe fruit stored at $25^{\circ} \mathrm{C}$ (3-day shelf life) and different from Mariano-Nasser et al. (2018), who found a 6-day storage period for fallen (mature) mangabas, regardless of storage conditions.
Harvesting ripe fruit shortened their shelf life due to the difficulties involved in handling them and their low physical resistance (CHITARRA; CHITARRA, 2005).

Given that they were collected from the ground, the ripe fruit had been damaged by the fall from the tree and therefore entered senescence more quickly when compared to "mature green" fruit. Additionally, mangaba collected from the ground had undergone fermentation (because it was impossible to know how many days had passed since they had fallen from the tree), which also contributed to their reaching senescence. These results demonstrate the importance of harvesting at physiological maturity ("mature green") in order to increase the shelf life of mangaba.

\section{Univariate analysis}

The AA levels of mangaba increased during storage (Tables 2 and 4); this is unusual behavior for fruit, which typically show a decline in AA after harvesting. However, ascorbic acid can remain constant or increase during storage for some types of fruit (CAVALINI, 2008; CAVALINI et al., 2006), as observed in the two mangaba varieties studied here. Increased AA in fruit may be related to the action of vitamin $\mathrm{C}$ as an antioxidant in response 
Bioactive compounds...

to oxidative reactions that occur during ripening (CARNELOSSI et al., 2004).

The ascorbic acid levels recorded for the gardneri and cuyabensis varieties, regardless of ripening stage (Tables 2 and 4), were lower than those reported by Carnelossi et al. (2004) of 274.7 $\mathrm{mg}$ ascorbic acid/100 g of pulp for "mature green" fruit and $252.7 \mathrm{mg}$ ascorbic acid $100 \mathrm{~g}^{-1}$ of pulp for "fallen" fruit. By contrast, Rufino et al. (2010) found similar values $\left(190 \mathrm{mg}\right.$ ascorbic acid $100 \mathrm{~g}^{-1}$ of pulp) to those recorded here for ripe mangaba. Almeida et al. (2011) found lower values $(96.3 \mathrm{mg}$ ascorbic acid $100 \mathrm{~g}^{-1}$ ) than those of this study. However, AA levels of both the varieties analyzed were higher than those found in fruit considered "superfruits" such as blueberries (18.15 mg $\left.100 \mathrm{~g}^{-1}\right)$, according to Silveira et al. (2007), and strawberries (43.66 mg ascorbic acid $100 \mathrm{~g}^{-1}$ ), in accordance with Cunha Junior et al. (2017).

From a nutritional perspective, high vitamin $\mathrm{C}$ levels in fruit are a desirable and important characteristic (SILVEIRA et al., 2007), meaning the mangaba has significant potential to provide consumers with numerous health benefits. Mendes (2015) compiled data on the nutritional composition of native fruit species and found a vitamin $\mathrm{C}$ content of $332 \mathrm{mg} 100 \mathrm{~g}^{-1}$ for mangaba, second only to camu camu (1888.2 mg $100 \mathrm{~g}^{-1}$ ). Thus, it shows potential as a "superfruit", since according to Ohr (2012), superfruits have high nutritional value due to their abundant nutrients and antioxidant properties, in addition to consumer appeal and a tendency to be more exotic.

Flavonoids are an important class of natural pigments that frequently occur in nature both in free form and as glycines associated with sugars and tannins, exclusively in plants (BOBBIO; BOBBIO, 2001). These non-nutritious compounds display antioxidant, antimutagenic and anticancer activity in different systems (ANDERSON et al., 2000).

In this study, flavonoid values did not differ between varieties in either ripening stage (Tables 2 and 4). Flavonoid content in "mature green" mangaba increased considerably on the last day of storage, possibly because of the biochemical changes that occur during ripening, such as the enzymatic degradation of chlorophyll and emergence of other colors due to the pigments responsible for fruit coloring (TADESSE et al., 1999). Moreover, yellow flavonoid values were five times higher in the ripe mangaba than "mature green" fruit and similar to those reported by Rufino et al. (2010) of $15 \mathrm{mg} 100 \mathrm{~g}^{-1}$ of pulp. Pedrosa (2018) also found differences in the flavonoid content of mature green mangaba varieties, with an
MORGADO, C. M. A. et al.

average value of $2.41 \mathrm{mg} 100 \mathrm{~g}^{-1}$ of pulp, which was lower than that obtained here.

Total extractable polyphenols (TEP) in "mature green" fruit were higher in the cuyabensis variety (Table 2 ) because phenolic compound levels vary between fruits. This variation (quantitative and qualitative) is associated with both intrinsic (variety and ripening stages) and extrinsic factors (soil and climate conditions) (MELO et al., 2008).

The PET levels recorded in this study were lower than those recorded by Rufino et al. (2010), who reported $170 \mathrm{mg}$ gallic acid $100 \mathrm{~g}^{-1}$ of pulp in fresh mangaba, albeit without specifying the variety. By contrast, Rocha et al. (2011) found similar levels to those obtained here for both varieties at the "mature green stage, although the authors did not identify the variety. These differences reinforce the need to study mangaba varieties separately since physiological behavior differs between varieties (GANGA et al., 2009), meaning that research conducted without identifying the variety may produce different results.

Ripe cuyabensis fruit exhibited a rise in TEP values during storage, possibly because these compounds are largely responsible for the color and flavor of different fruit (CHEYNIER, 2012), and the biochemical changes that occur during ripening may cause an increase in polyphenol levels.

Antioxidant activity measured by FRAP in "fallen" fruit was similar to that reported by Rufino et al. (2010), although the authors obtained higher values than those observed here for "mature green" mangaba. Antioxidant activity varies according to the variety studied, crop treatments applied in the field, processing method used and the ripening stage at which the fruit was harvested.

Total AA determined by ABTS revealed lower values for both ripening stages and varieties when compared to those observed by Rufino et al. (2010). However, Lima (2011) evaluated the behavior of antioxidant activity in mangaba during storage and corroborated the results obtained here for each variety (Table 3), namely a tendency for values to decline across the storage period.

Results for undomesticated fruit show substantial differences in absolute values, as demonstrated in this study. Since these plants are largely in their natural habitat, factors such as location, pre-and post-harvest management strategies, sun exposure, climate and ripening stage influence the composition of these fruit (MARTINS et al., 2011).

The genetic differences of each mangaba variety are also important factors in the metabolism of antioxidant compounds, as highlighted by Silva et 
al. (2015), who studied fruit from different accessions of the Embrapa Tabuleiros Costeiros Mangaba Germplasm, obtaining values of 3.91 to $12.20 \mu \mathrm{M}$ of trolox $\mathrm{g}^{-1}$. It is important to underscore that changing the harvesting time, that is, no longer using fallen fruit, results in a four-fold longer shelf life and a fruit that is still rich in these healthy compounds on the eighth day. Both Pedrosa (2018) and Zuninga et al. (2018) found that mangaba exhibit high antioxidant capacity, confirming its potential as a "superfruit".

It is noteworthy that the bioactive compounds and total antioxidant activity of both mangaba varieties were little affected by storage, demonstrating its potential since these components were still present in significant amounts after 8 days of storage ("mature green").

\section{Multivariate analysis}

Although univariate analysis proved highly informative, the approach did not make it possible to identify the relationships between quality parameters.

Analysis of the biplot indicated that all the parameters assessed acted positively on the left side. This demonstrates that, regardless of variety, the ripe mangaba collected showed higher ascorbic acid levels, yellow flavonoid content, total extractable polyphenols and total antioxidant activity (Figure 2 ), confirming the results of the univariate analysis.

The fact that ripe mangaba contained more bioactive compounds and showed greater antioxidant activity when compared to "mature green" fruit can be explained by the chemical and biochemical changes that occur during ripening. Moreover, AA generally increases as ripeness progresses (CARNELOSSI et al., 2004), as observed in this study, where ripe mangaba showed greater antioxidant activity irrespective of variety.

Another important point is the influence of the genetic factor on the quality parameters assessed in the two varieties. In the cuyabensis variety, higher ascorbic acid levels, total extractable polyphenols and total antioxidant activity were observed in "mature green" fruit (regardless of the method used) when compared to gardneri, since the samples of the latter were positioned on the opposite side to vectors corresponding to each parameter assessed (Figure 2). Furthermore, the genetic factor of each variety may have influenced their division in dendrogram formation (Figure 1) when collected at the "mature green" stage. This can be explained by the findings of Melo et al. (2008), who reported that ascorbic acid content, phenolic compounds and antioxidant activity may vary according to variety and ripening stage.

The results obtained here demonstrate the potential of existing mangaba varieties, with compounds that could diversify the eating habits and nutrition of consumers, supplementing a healthy diet.

\section{CONCLUSIONS}

The "mature green" stage is the most suitable for harvesting mangaba, regardless of variety, because it results in a longer shelf life when compared to ripe fruit.

Cuyabensis fruit harvested at physiological maturity ("mature green") showed greater potential, since its bioactive compound content and antioxidant activity were superior to the gardneri variety.

\section{ACKNOWLEDGMENTS}

The authors are grateful to the Nutrition and Food Analysis Laboratory of the School of Nutrition at the Federal University of Goiás, particularly Prof. Maria Aderuza Horst; to the Graduate Agronomy Program (Plant Production) of the Federal University of Goiás for its support and the National Postdoctoral Program (PNPD/CAPES) for the grant awarded to the first author.

RESUMO: O presente trabalho objetivou avaliar o comportamento dos compostos bioativos e da atividade antioxidante total de duas variedades de mangaba (H. speciosa var. gardneri e $H$. speciosa var. cuyabensis) durante o armazenamento, em dois estádios de maturação. Os frutos foram colhidos no banco de Germoplasma da Escola de Agronomia, em dois estádios de maturação, "de vez" (frutos maturos colhidos da árvore) e "de caída" (frutos maduros coletados no chão). Após a colheita, foram transportados para o laboratório, onde foram selecionados, lavados em água corrente, imersos em solução de cloro a $100 \mathrm{mg} \mathrm{L}^{-1}$ por 10 minutos, deixados secar e armazenados sob condição ambiente $\left(22 \pm 1^{\circ} \mathrm{C}\right.$ e $90 \pm 5 \%$ UR). Os frutos foram analisados quanto aos teores de ácido ascórbico, flavonoides amarelos e polifenóis extraíveis totais, além da atividade antioxidante total determinada pelo método de redução do ferro (FRAP) e ABTS (2,2'-azino-bis-(3ethylbenzthiazoline-6-sulfonic acid). As análises foram realizadas diariamente até que os frutos se tornassem impróprios para a comercialização, utilizando-se 3 repetições com 3 frutos cada. O período máximo de 
conservação foi de oito dias para os frutos "de vez" e dois dias para os frutos "de caída". A variedade cuyabensis apresentou maiores teores de ácido ascórbico em ambos os estádios de maturação avaliados, além da capacidade antioxidante mais elevada, mostrando ser a variedade com maior potencial para "superfruta" na comercialização.

PALAVRAS-CHAVE: Capacidade antioxidante, Cerrado, $H$. speciosa var. cuyabensis, $H$. speciosa var. gardneri.

\section{REFERENCES}

ALMEIDA, M. M. B.; SOUSA, P. H. M.; ARRIAGA, A. M. C.; PRADO, G. M.; MAGALHÃES, C. E. C.; MAIA, G. A.; LEMOS; T. L. G. Bioactive compounds and antioxidant activity of fresh exotic fruits from northeastern Brasil. Food Research International, v. 44, n. 7, p. 2155-2159, 2011.

https://doi.org/10.1016/j.foodres.2011.03.051.

AOAC. Official Methods of Analysis of AOAC international. 19. ed. AOAC 54 International, Gaithersburg, Maryland, USA. 2012.

ANDERSON, R. F.; AMARASINGHE, C.; FISHER, L. J.; MAK, W. B.; PACKER, J. E. Reduction in freeradical- induced DNA strand breaks and base damage through fast chemical repair by flavonoids. Free Radical Research, v. 33, n. 1, p. 91-103, 2000. https://doi.org/10.1080/10715760000300651.

BENZIE, I. F. F.; STRAIN, J. J. The ferric reducing ability of plasma (FRAP) as a measure of antioxidant power: the FRAP assay. Analytical Biochemistry. v. 239, p. 70-76, 1996.

BOBBIO, P. A.; BOBBIO, F. O. Química do processamento de alimentos. 3. ed., São Paulo: Varela. 2001. CALBO, A. G.; NERY, A. A. Medida de firmeza em hortaliças pela técnica de aplanação. Horticultura Brasileira, v. 3, n. 1, p. 14-18, 1995.

CALDAS, L. S.; MACHADO, L. L.; CALDAS, S. C.; CAMPOS, M. L.; CALDAS, J. A.; PHARIS, R. P.; PEREIRA-NETO, A. B. Growth active gibberellins overcome the very slow shoot growth of Hancornia speciosa, an important fruit tree from the Brazilian Cerrado. Trees, v. 23, p. 1229-1235, 2009.

https://doi.org/10.1007/ s00468-009-0361-9.

CAMPOS, R. P.; KNOCH, B.; HIANE, P. A.; RAMOS, M. I. L; RAMOS FILHO, M. M. R. 1-MCP em mangabas armazenadas em temperatura ambiente e a $11^{\circ} \mathrm{C}$. Revista Brasileira de Fruticultura, v. E, n. spe1, p. 206-212, 2011. https://doi.org/10.1590/S0100-29452011000500024.

CARDOSO, L. M. Araticum, cagaita, jatobá, mangaba e pequi do Cerrado de Minas Gerais: ocorrência e conteúdo de carotenoides e vitaminas. Universidade Federal de Viçosa, Viçosa, 61f. 2011. Dissertação de Mestrado.

CARNELOSSI, M. A. G.; TOLEDO, W. F. F.; SOUZA, D. C. L.; LIRA, M. L.; SILVA, G. F.; JALALI, V. R. R.; VIÉGAS, P. R. Conservação pós-colheita de mangaba (Hancornia speciosa Gomes). Ciência e Agrotecnologia, v. 28, n.5, p. 1119-1125, 2004. https://doi.org/10.1590/S1413-70542004000500021.

CAVALINI, F. C. Fisiologia do amadurecimento, senescência e comportamento respiratório de goiabas 'Kumagai' e 'Pedro Sato'. Universidade de São Paulo, Piracicaba, 90f. 2008. Tese de Doutorado.

CAVALINI, F. C.; JACOMINO, A. P.; LOCHOSKI, M. A.; KLUGE, R. A.; ORTEGA, E. M. M. Maturity indexes for 'Kumagai' and 'Paluma' guavas. Revista Brasileira de Fruticultura, v. 28, n.2, p. 176- 179, 2006. https://doi.org/10.1590/S0100-29452006000200005. 
Bioactive compounds...

MORGADO, C. M. A. et al.

CHEYNIER, V. Phenolic compounds: From plants to foods. Phytochemistry Reviews, v. 11, n. 2-3, 2012. https://doi.org/10.1007/s11101-012-9242-8.

CHITARRA, M. I. F.; CHITARRA, A. B. Pós-colheita de frutos e hortaliças: fisiologia e manuseio. 2. ed. rev. e ampl. Lavras: UFLA, 2005. 785p.

COLleVATTI, R. G.; OliVATTI, A. M.; TELLES, M. P. C.; CHAVES, L. J. Gene flow among Hancornia speciosa (Apocynaceae) varieties and hybrid fitness. Tree Genetics \& Genomes, v. 12, p. 74, 2016. https://doi.org/10.1007/s11295-016-1031-x.

CUNHA JUNIOR, L. C.; MORGADO, C. M. A.; JACOMINO, A. P.; TREVISAN, M. J., PARISI, M. C. M.; NASCIMENTO, A. R. Embalagem alternativa para cadeia produtiva de morango. Revista de Ciências Agrárias, v. 40, n. 2, p. 342-352, 2017. https://doi.org/10.19084/RCA16155.

FERREIRA, D. F. Sisvar: a Guide for its bootstrap procedures in multiple comparisons. Ciência e Agrotecnologia, v. 38, n. 2, p. 109-112, 2014. https://doi.org/10.1590/S1413-70542014000200001.

FRANCIS, F. J. Analysis of anthocyanins. In: Markakis, P. (ed.). Anthocyanins as food colors. New York: Academic Press. 1982.

GANGA, R. M. D. Variabilidade de plantas e progênies de populações naturais de Hancornia speciosa Gomes do Cerrado. Universidade Federal de Goiás, Goiânia, 126f. 2008. Tese de Doutorado.

GANGA, R. M. D.; CHAVES, L. J.; NAVES, R. V. Parâmetros genéticos em progênies de Hancornia speciosa Gomes do Cerrado. Scientia Forestalis, v. 37, n. 84, p. 395-404, 2009.

HAIR JR., J. F.; BLACK, W. C.; BABIN, B. J.; ANDERSON, R. E. Multivariate data analysis: a global perspective. 7 ed. London: Pearson Education, 2009. 800p.

KAISER, H. F. The varimax criterion for analytic rotation in factor analysis. Psychometrika, v. 23, n. 3, p. 187-200, 1958. https://doi.org/10.1007/BF02289233.

LEDERMAN, I. E.; SILVA JUNIOR, J. F.; BEZERRA, J. E. F.; ESPÍNDOLA, A. C. M. Mangaba (Hancornia speciosa Gomez). In: LENDERMAN, I. E. Série frutas nativas. Jaboticabal: Funep. 2000.

LEE, S. K.; KADER, A. A. Preharvest and postharvest factors influencing vitamin C content of horticultural crops. Postharvest Biology and Technology, v. 20, n. 3, p. 207-220, 2000. https://doi.org/10.1016/S09255214(00)00133-2.

LIMA, A. C.; GARCIA, N. H. P.; LIMA, J. R. Obtenção e caracterização dos principais produtos do caju. Boletim Centro de Pesquisa de Processamento de Ảlimentos, v. 22, n. 1, p. 133-144, 2004. https://doi.org/10.5380/cep.v22i1.1185.

LIMA, J. P. Qualidade pós-colheita, atividade antioxidante "in vitro" e perfil volátil da mangaba (Hancornia speciosa) submetida à refrigeração e atmosfera modificada. Universidade Federal e Lavras, Lavras, 94f. 2011. Dissertação de Mestrado.

MARIANO-NASSER, F. A. C.; BOLIANI, A. C.; NASSER, M. D.; ALVES-PRADO, H. F.; PAGLIARINI, M. K.; MOREIRA, E. R. Modified passive atmosphere in post-harvest mangaba fruit conservation in three maturity degrees. ColloquiumAgrariae, v. 14, n. 2, p. 111-121, 2018.

https://doi.org/10.5747/ca.2018.v14.n2.a211.

MARTINS, S.; MUSSATTO, S. I.; MARTÍNEZ-AVILA, G.; MONTANEZ-SAENZ, J.; AGUILAR, C. N.; TEXEIRA, J. A. Bioactive phenolic compounds: production and extraction by solid-state fermentation. A 
review. Biotechnology Advances, v. 29, n. 3, p. 365-373, 2011.

https://doi.org/10.1016/j.biotechadv.2011.01.008.

MATTOS, P. L. P.; ALMEIDA, P. A. Colheita. In: Aspectos sócioeconômicos e agronômicos da mandioca. Cruz das Almas: Embrapa Mandioca e Fruticultura Tropical. 2006.

MELO, E. A.; MACIEL, M. I. S.; LIMA, V. L. A. G.; NASCIMENTO, R. J. Capacidade antioxidante de frutas. Revista Brasileira de Ciências Farmacêuticas, v. 44, n. 2, p. 193-201, 2008. https://doi.org/10.1590/S1516-93322008000200005.

MENDES, R. J. S. Biodiversidade e composição de alimentos: dados nutricionais de frutas nativas subutilizadas da flora brasileira. Universidade de São Paulo, São Paulo, 111f. 2015. Dissertação de Mestrado.

MOKADY, S.; COGAN, U.; LIEBERMAN, L. Stability of vitamin C in fruits and fruit blends. Science of Food and Agriculture, v. 35, p. 452-456, 1984. https://doi.org/10.1002/jsfa.2740350415.

MORGADO, C. M. A.; DURIGAN, J. F.; LOPES, V. G.; SANTOS, L. O. Conservação pós-colheita de goiabas 'Kumagai': efeito do estádio de maturação e da temperatura de armazenamento. Revista Brasileira de Fruticultura, v. 32, p. 1001-1008, 2010. http://dx.doi.org/10.1590/S0100-29452010000400008.

OBANDA, M.; OWUOR, P. O. Flavonol Composition and caffeine content of green leaf as quality potential indicators of kenyan black teas. Science of Food and Agriculture, v. 74, p. 209-215, 1997.

https://doi.org/10.1002/(SICI)1097-0010(199706)74:2<209::AID-JSFA789>3.0.CO;2-4.

OHR, L. M. Fruitful yields. Food Technology, v. 66, p. 103-110, 2012.

PARK, Y. S.; JUNG, S. T.; KANG, S. G.; DRZEWIECKI, J.; NAMIESNIK, J.; HARUENKIT, R. In vitro studies of polyphenols, antioxidants and other dietary indices in kiwifruit (Actinidia deliciosa). International Journal of Food Sciences and Nutrition, v. 57, p. 107-122, 2006.

https://doi.org/10.1080/09637480600658385.

PEDROSA, V. M. D. Fisiologia, qualidade e potencial de frutos de diferentes acessos de mangabeira (Hancornia speciosa). Universidade Federal da Paraíba, 57 f. 2018. Monografia.

PRASANNA, V.; PRABHA, T. N.; THARANATHAN, R. N. Fruit Ripening Phenomena-An Overview, Critical Reviews in Food Science and Nutrition, v. 47, n. 1, p. 1-19, 2007.

https://doi.org/10.1080/10408390600976841.

PRIOR, R. L.; WU, X.; SCHAICH, K. Standardized methods for the determination of antioxidant capacity and phenolics in foods and dietary supplements. Journal of Agricultural and Food Chemistry, v. 53, n. 10, p. 4290-4302, 2005. https://doi.org/10.1021/jf0502698.

PULIDO, R.; BRAVO, L.; SAURA-CALIXTO, F. Antioxidant activity of dietary polyphenols as determined by a modified ferric reducing antioxidant power assay. Journal of Agricultural and Food Chemistry. v. 48, p. 3396-3402, 2000.

ROCHA, W. S.; LOPES, R. M.; SILVA, D. B.; VIEIRA, R. F.; SILVA, J. P.; AGOSTINI-COSTA, T. S. Compostos fenólicos totais e taninos condensados em frutas nativas do Cerrado. Revista Brasileira de Fruticultura, v. 33, n. 4, p. 1215-1221, 2011. https://doi.org/10.1590/S0100-29452011000400021.

RUFINO, M. S. M. Propriedades funcionais de frutas tropicais brasileiras não tradicionais. Universidade Federal Rural do Semi-Árido, Mossoró, 237f. 2008. Tese de Doutorado. 
RUFINO, M. S. M.; ALVES, R. E.; BRITO, E. S.; PÉREZ-JIMÉNEZ, J.; SAURA-CALIXTO, F.; MANCINIFILHO, J. Bioactive compounds and antioxidant capacities of 18 non-traditional tropical fruits from Brazil. Food Chemistry, v. 121, n. 4, p. 996-1002, 2010. https://doi.org/10.1016/j.foodchem.2010.01.037.

SANTOS, L.O. Armazenamento refrigerado, atmosfera controlada e desverdecimento de tangerinas. Universidade Estadual Paulista "Julio de Mesquita Filho", Jaboticabal, 143f. 2011. Tese de Doutorado.

SANTOS, A. F. D.; SILVA, S. M.; MENDONÇA, R. M. N.; ALVES, R. E. Conservação pós-colheita de mangabas em função da maturação, atmosfera e temperatura de armazenamento. Ciência e Tecnologia de Alimentos, v. 29, n. 1, p. 85-91, 2009. https://doi.org/10.1590/S0101-20612009000100014.

SILVA, A. V. C. DA; YAGUIU, P.; MUNIZ, E. N.; VITÓRIA, M. F.; AMORIM, J. A. E. Vida útil de mangaba colhida em dois estádios de maturação. Aracaju: Embrapa Tabuleiros Costeiros, 2013. 15p. (Boletim de Pesquisa/Embrapa Tabuleiros Costeiros, ISSN 1678-1961; 80).

SILVA, A. V. C. DA S.; SILVA JUNIOR, J. F. DA; MOURA, C. F. H.; MENEZES, D. N. B.; VITÓRIA, M. F. DA; AMORIM, J. A. Atributos de qualidade e funcionais de acessos do banco ativo de germoplasma de mangaba da Embrapa Tabuleiros Costeiros. Aracaju, SE: Embrapa Tabuleiros Costeiros. (Embrapa Tabuleiros Costeiros. Circular Técnica, 71, ISSN 1678-1945). 2015.

SILVEIRA, N.G.A.; VARGAS, P.N.; ROSA, C.S. Teor de polifenóis e composição química do mirtilo do grupo highbush. Alimentos e nutrição, v. 18, n. 4, p. 365-370, 2007.

SOARES, F. P.; PAIVA, R.; NOGUEIRA, R. C.; OLIVEIRA, L. M. DE; SILVA, D. R. G.; PAIVA, P. D. DE O. Cultura da Mangabeira (Hancornia speciosa Gomes). Boletim Agropecuário Universidade Federal de Lavras, v. 67, p. 1-12, 2004.

SOUZA, F. B. M. de. Fenologia, produção e qualidade dos frutos de cultivares e seleções de pessegueiro na Serra da Mantiqueira. Universidade Federal de Lavras, Lavras, 72f. 2012. Dissertação de Mestrado.

STATSOFT. STATISTICA (data analysis software system). Version 7.0. Cary, 2004.

STROHECKER, R.; HENINING, H. M. Análisis de vitaminas: métodos comprobrados, 1967. 42p.

TADESSE, T.; NICHOLS, M. A.; FISHER, K. J. Nutrient conductivity effects on sweet pepper plants grown using a nutrient film technique. New Zealand Journal of Crop and Horticultural Science, v. 27, n. 3, p. 229237, 1999. https://doi.org/10.1080/01140671.1999.9514101.

VIEIRA NETO, R. D.; CINTRA, F. L. D.; SILVA, A. L.; SILVA JÚNIOR, J. F.; COSTA, J. L. S.; SILVA, A. A. G.; CUENCA, M. A. G. Sistema de produção de mangaba para os tabuleiros costeiros e baixada litorânea. Aracaju: Embrapa Tabuleiros Costeiros, 2002. 22p.

VIEIRA, R. F., AGOSTINI-COSTA, T. S.; SILVA, D. B.; SANO, S. M.; FERREIRA, F. R. Frutas nativas da região Centro-oeste do Brasil. Embrapa Informação Tecnológica, 2010. 322p.

XIAO, J. B. Phytochemicals in food and nutrition. Critical Reviews in Food Science and Nutrition, v. 56, n. S1-S3, 2016. https://doi.org/10.1080/10408398.2015.1111074.

ZHANG, X.; KOO, J.; EUN, J. B. Antioxidant activities of methanol extracts and phenolic compounds in Asian pear at different stages of maturity. Food Science and Biotechnology, v. 15, n. 1, p. 44-50, 2006.

ZUNINGA, A.; COQUEIRO, K. T. O.; SIQUEIRA, M. A. S. Phytochemical characterization of native fruits of cerrado (Hancorniaspeciosa, Campomanesiaxanthocarpa, Eugenia dysenterica) a brief review. Revista Desafios, v. 5, n. 1, 2018. 